自治体広報紙のアーカイブ化の現状と課題

\title{
Current Conditions and Issues of Archiving of Local Government
}

\section{Public Relations Paper}

\author{
本田正美 ${ }^{1 *}$ \\ Masami HONDA ${ }^{1 *}$
}

\section{1 東京大学大学院学際情報学府博士課程}

Graduate School of Interdisciplinary Information Studies, The University of Tokyo

\section{干113-0033 東京都文京区本郷7-3-1}

E-mail:qq56121@iii.u-tokyo.ac.jp

*連絡先著者

自治体における電子化の進展に伴い、自治体が保有する情報の電子化も進み、その一部は自治 体のWebサイト上で公開されるに至っている。しかし、現状では、利用者が公開された情報を再 利用することは想定されず、保有する情報を単に電子化するに留まっている。本研究では、自治 体が発行している広報紙を題材にして、自治体が保有する情報のアーカイブ化の現状と課題を確 認する。

With progress of the digitization in the local government, the digitization of the information that the local government holds advances, and some of which are to be published on the Web site of the local government. However, under the present conditions, to re-use the information that is published is not assumed. It has remained in that information to hold it being merely computerized. In this study, it focuses on the local government public relations paper and confirms the present conditions and issues of archiving of information that the local government holds.

キーワード: 電子政府, 自治体広報紙, 自治体Webサイト, アーカイブ

Keyword : E-Government, Local Government Public Relations Paper, Local Government Web Site, Archive

\section{1 はじめに}

本研究は，自治体が発行する広報紙のア

一カイブ化の現状と課題を確認すること を目的とする。
自治体における電子化の進展に伴い，自 治体が保有する情報の電子化も進み，その 一部は自治体のWebサイト上で公開され るに至っている。しかし，現状では，利用 
者が公開された情報を再利用することは 想定されず，保有する情報を単に電子化す るに留まっている.

広報紙のアーカイブ化については，広報 紙の作成等を担当する部署が発行した広 報紙を公開可能な形で保管していれば，そ れをもってアーカイブ化がなされている と考えることも出来るが，本研究では， Web 経由で閲覧可能な状態にまで整理さ れることをもって，アーカイブ化がなされ たと解する。 これは，デジタル技術を活用 して収蔵物をアーカイブ化したもの，さら に，散財寸る対象物そのものの代わりにデ ジタルデータを対象としてアーカイブし たものなどを, デジタルアーカイブとした 笠羽[1]の定義と軌を一にする考え方であ る，本研究では，自治体のWebサイトにお いて広報紙が公開されているのか否か，さ らに，どのような形態で公開されているの か. どの程度の蓄積があるのか. 以上の点 を確認することで，広報紙のアーカイブ化 の現状と課題について論じる.

\section{2 自治体広報紙の現状調査}

\section{1 調查の概要}

本研究における調査では, 2012 年 4 月 14 日から 19 日まで，全国の市町村（特 別区を含む）のWeb サイトを閲覧し，広 報紙の Web サイト上での公開の有無と 公開される形態を確認した。閲覧する各 自治体の Web サイトは，LASDEC が提 供している全国自治体マップ検索 (https://www.lasdec.or.jp/cms/1,0,69.ht $\mathrm{ml})$ に登録されたサイトとした。

調査対象は，全国の市町村と東京都の 特別区であり，計 1742 自治体である.
広報紙の公開の有無などの確認にあた っては，Webサイトのトップページからリ ンクがなされている場合は，それに従って 広報紙が公開されているページにアクセ ス寸ることとし，トップページからアクセ 不出来ない場合, サイト内検索があるとき には，それを利用し，無いときにはGoogle 検索で，当該市町村名に「広報」と付けて 検索することで，該当するページを探索し た。また，全国の自治体のWebサイト上で 公開されている広報紙の所在を示した自 治体ドットコムの全国広報紙一覧 (http://www.jichitai.com/joho/koho/) も 参 照した．複数の方法により，広報紙がWeb サイト上で公開されていないと思しき自 治体について見落としがないよう努めた。

\section{2 調査項目}

調査項目は，各自治体において発行され た広報紙のWebサイト上での公開の有無 と公開されるデータの形態, 公開されてい る年数である。

公開の有無については，1号分のみの公 開であっても，Webサイト上で何らかの形 式で広報紙が公開されている場合，公開さ れているものと見做した.

公開されているデータの形態については, 基本的にはデータのファイルの識別子に より判断した。 なお，独自のビューワーを 提供している場合やスマートフォン向け の公開方法を提供している事例が見られ る。これについては，データの形態におけ る分類には含めていない。その結果，公開 されるデータの形態は, PDF・TXT・ JPEG・GIF・HTML(広報を素材とした独 自のページ開設を含む)であり, 複数を併用 している例も見られる。 
年数については, 2012 年内のみの公開に ついては，0年と換算した。よって，最新 号のみWebサイト上で公開している場合， 公開は「有」で，年数は「0年」となる. 2011年より前については，該当する年につ いて1号でもWeb上で公開されているもの があれば1年と換算し，抜けている年につ いては加算せずに，累積の年数を計算した。

\section{3 調査結果}

調査の結果は，以下の通りである.

\begin{tabular}{|c|c|c|}
\hline & \multicolumn{2}{|c|}{ （自治体数 N=1742） } \\
\hline & 有 & 無 \\
\hline Web サイト上の公開 & 1718 & 24 \\
\hline データの形式 & PDF & PDF/HTML \\
\hline 自治体数 & 1566 & 99 \\
\hline & PDF/JPEG & PDF/TXT \\
\hline & 17 & 16 \\
\hline & $\mathrm{PDF} / \mathrm{GIF}$ & HTML \\
\hline & 1 & 15 \\
\hline & JPEG & GIF など \\
\hline & 2 & 2 \\
\hline 平均年数 & 6.9 年 & \\
\hline
\end{tabular}

表1 自治体広報紙のWebサイト上の公開の 全国的な状況

広報紙を Web サイト上で公開してい ない市町村は，少数である. Web サイト 上で広報を公開していない 24 自治体の うち半数の 12 自治体が人口 2000 人以下 の小規模な自治体である(2005 年時点の 人口). Web サイト自体は全自治体で開設 されているが，広報紙の公開にまで手が 回っていない自治体が存在している.

公開されるデータの形態は PDF が大 半であり，その他には，PDF と併用で HTML などが利用されている。読み上げ
ソフトの利用を想定して, テクスト形式 (TXT)で公開するように努めている例が 見受けられることが注目される.

公開されている年数の全国平均は，6.9 年である。ただし，この年数は一部の長期 公開年数を誇る自治体により若干押し上 げられている。それは，以下の表2を見る と確認出来る。その中で，例えば，秋田県 は秋田市と能代市と大館市が 60 年分以上, 大仙市と北秋田市が50年分以上の広報紙 を公開しているゆえに，平均年数が長い. その他, 平均年数が 10 年を超えるコホート には，50年以上の公開年数を含む自治体が 含まれている。

\begin{tabular}{|l|r|r|r|}
\hline 北海道 & $\begin{array}{l}\text { 広報掲載な } \\
\text { L }\end{array}$ & $\begin{array}{l}\text { 非 PDF 単 } \\
\text { 独 }\end{array}$ & $\begin{array}{l}\text { 平均年 } \\
\text { 数 }\end{array}$ \\
\hline 市 $(\mathrm{N}=35)$ & 0 & 5 & 9.0 \\
\hline $\begin{array}{l}\text { 町村 } \\
(\mathrm{N}=144)\end{array}$ & 0 & 4 & 5.3 \\
\hline
\end{tabular}

\begin{tabular}{|l|r|r|r|}
\hline 青森 & $\begin{array}{l}\text { 広報掲載な } \\
\text { L }\end{array}$ & $\begin{array}{l}\text { 非 PDF 単 } \\
\text { 独 }\end{array}$ & $\begin{array}{l}\text { 平均年 } \\
\text { 数 }\end{array}$ \\
\hline 市 $(\mathrm{N}=10)$ & 0 & 0 & 6.3 \\
\hline 町村 $(\mathrm{N}=30)$ & 0 & 0 & 8.2 \\
\hline
\end{tabular}

\begin{tabular}{|l|r|r|r|}
\hline 岩手 & $\begin{array}{l}\text { 広報掲載な } \\
\text { L 非 PDF 単 }\end{array}$ & $\begin{array}{l}\text { 平均年 } \\
\text { 数 }\end{array}$ \\
\hline 市 $(\mathrm{N}=13)$ & 0 & 0 & 9.0 \\
\hline 町村 $(\mathrm{N}=20)$ & 0 & 0 & 8.7 \\
\hline
\end{tabular}

\begin{tabular}{|l|r|r|r|}
\hline 宮城 & \multicolumn{2}{|l|}{$\begin{array}{l}\text { 広報掲載な } \\
\text { L 非 PDF 単 }\end{array}$} & $\begin{array}{l}\text { 平均年 } \\
\text { 独 }\end{array}$ \\
\hline 市 $(\mathrm{N}=13)$ & 0 & 1 & 9.5 \\
\hline 町村 $(\mathrm{N}=22)$ & 0 & 0 & 3.9 \\
\hline
\end{tabular}

\begin{tabular}{|l|r|r|r|}
\hline 秋田 & $\begin{array}{l}\text { 広報掲載な } \\
\text { L 非 PDF 単 }\end{array}$ & $\begin{array}{l}\text { 平均年 } \\
\text { 独 }\end{array}$ \\
\hline 数 \\
\hline 市 $(\mathrm{N}=13)$ & 0 & 3 & 28.2 \\
\hline 町村 $(\mathrm{N}=12)$ & 0 & 0 & 6.7 \\
\hline
\end{tabular}

\begin{tabular}{|l|r|r|r|}
\hline 山形 & $\begin{array}{l}\text { 広報掲載な } \\
\text { L }\end{array}$ & $\begin{array}{l}\text { 非 PDF 単 } \\
\text { 独 }\end{array}$ & $\begin{array}{l}\text { 平均年 } \\
\text { 数 }\end{array}$ \\
\hline 市 $(\mathrm{N}=13)$ & 0 & 0 & 4.8 \\
\hline 町村 $(\mathrm{N}=22)$ & 0 & 0 & 4.8 \\
\hline
\end{tabular}




\begin{tabular}{|l|r|r|r|}
\hline 福島 & $\begin{array}{l}\text { 広報掲載な } \\
\text { L }\end{array}$ & $\begin{array}{l}\text { 非 PDF 単 } \\
\text { 独 }\end{array}$ & $\begin{array}{l}\text { 平均年 } \\
\text { 数 }\end{array}$ \\
\hline 市 $(\mathrm{N}=13)$ & 1 & 1 & 5.3 \\
\hline 町村 $(\mathrm{N}=46)$ & 1 & 2 & 5.9 \\
\hline
\end{tabular}

\begin{tabular}{|l|r|r|r|}
\hline 茨城 & $\begin{array}{l}\text { 広報掲載な } \\
\text { L }\end{array}$ & $\begin{array}{l}\text { 非 PDF 単 } \\
\text { 独 }\end{array}$ & $\begin{array}{l}\text { 平均年 } \\
\text { 数 }\end{array}$ \\
\hline 市 $(\mathrm{N}=32)$ & 0 & 2 & 6.0 \\
\hline 町村 $(\mathrm{N}=12)$ & 0 & 0 & 5.0 \\
\hline
\end{tabular}

\begin{tabular}{|l|r|r|r|}
\hline 杤木 & $\begin{array}{l}\text { 広報掲載な } \\
\text { L 非 PDF 単 }\end{array}$ & $\begin{array}{l}\text { 平均年 } \\
\text { 独 }\end{array}$ & 数 \\
\hline 市 $(\mathrm{N}=14)$ & 0 & 1 & 4.7 \\
\hline 町村 $(\mathrm{N}=12)$ & 0 & 0 & 5.5 \\
\hline
\end{tabular}

\begin{tabular}{|c|c|c|c|}
\hline 群馬 & $\begin{array}{l}\text { 広報掲載な } \\
\text { し }\end{array}$ & $\begin{array}{l}\text { 非 PDF 単 } \\
\text { 独 }\end{array}$ & $\begin{array}{l}\text { 平均年 } \\
\text { 数 }\end{array}$ \\
\hline 市 (N=12) & 0 & 2 & 6.0 \\
\hline 町村 (N=23) & 1 & 6 & 5.2 \\
\hline
\end{tabular}

\begin{tabular}{|l|r|r|r|}
\hline 埼玉 & $\begin{array}{l}\text { 広報掲載な } \\
\text { L }\end{array}$ & $\begin{array}{l}\text { 非 PDF 単 } \\
\text { 独 }\end{array}$ & $\begin{array}{l}\text { 平均年 } \\
\text { 数 }\end{array}$ \\
\hline 市 $(\mathrm{N}=39)$ & 0 & 7 & 10.2 \\
\hline 町村 $(\mathrm{N}=24)$ & 1 & 0 & 5.3 \\
\hline
\end{tabular}

\begin{tabular}{|l|r|r|r|}
\hline 千葉 & $\begin{array}{l}\text { 広報掲載な } \\
\text { L }\end{array}$ & $\begin{array}{l}\text { 非 PDF 単 } \\
\text { 独 }\end{array}$ & $\begin{array}{l}\text { 平均年 } \\
\text { 数 }\end{array}$ \\
\hline 市 $(\mathrm{N}=36)$ & 0 & 2 & 8.3 \\
\hline 町村 $(\mathrm{N}=18)$ & 0 & 0 & 8.0 \\
\hline
\end{tabular}

\begin{tabular}{|l|r|r|r|}
\hline 東京 & $\begin{array}{l}\text { 広報掲載な } \\
\text { L }\end{array}$ & $\begin{array}{l}\text { 非 PDF 単 } \\
\text { 独 }\end{array}$ & $\begin{array}{l}\text { 平均年 } \\
\text { 数 }\end{array}$ \\
\hline $\begin{array}{l}\text { 特別区 } \\
(\mathrm{N}=23)\end{array}$ & 0 & 7 & 5.1 \\
\hline 市 $(\mathrm{N}=26)$ & 0 & 11 & 6.9 \\
\hline 町村 $(\mathrm{N}=13)$ & 1 & 0 & 4.2 \\
\hline
\end{tabular}

\begin{tabular}{|l|r|r|r|}
\hline 神奈川 & \multicolumn{2}{|l|}{$\begin{array}{l}\text { 広報掲載な } \\
\text { 乙 非 PDF 単 }\end{array}$} & $\begin{array}{l}\text { 平均年 } \\
\text { 独 }\end{array}$ \\
\hline 数
\end{tabular}

\begin{tabular}{|c|c|c|c|}
\hline 新潟 & $\begin{array}{l}\text { 広報掲載な } \\
\text { し }\end{array}$ & $\begin{array}{l}\text { 非 PDF 単 } \\
\text { 独 }\end{array}$ & $\begin{array}{l}\text { 平均年 } \\
\text { 数 }\end{array}$ \\
\hline 市 $(\mathrm{N}=20)$ & 0 & 1 & 9.0 \\
\hline 町村 ( $\mathrm{N}=10)$ & 1 & 0 & 6.5 \\
\hline
\end{tabular}

\begin{tabular}{|l|l|l|l|}
\hline 富山 & $\begin{array}{l}\text { 広報掲載な } \\
\text { L }\end{array}$ & $\begin{array}{l}\text { 非 PDF 単 } \\
\text { 独 }\end{array}$ & $\begin{array}{l}\text { 平均年 } \\
\text { 数 }\end{array}$ \\
\hline
\end{tabular}

\begin{tabular}{|l|r|r|r|} 
市 $(\mathrm{N}=10)$ & 0 & 2 & 4.8 \\
\hline 町村 $(\mathrm{N}=5)$ & 0 & 1 & 10.0 \\
\hline
\end{tabular}

\begin{tabular}{|c|c|c|c|}
\hline 石川 & $\begin{array}{l}\text { 広報掲載な } \\
\text { 乙 }\end{array}$ & $\begin{array}{l}\text { 非 PDF 単 } \\
\text { 独 }\end{array}$ & $\begin{array}{l}\text { 平均年 } \\
\text { 数 }\end{array}$ \\
\hline 市 $(\mathrm{N}=10)$ & 2 & 0 & 5.5 \\
\hline 町村 (N=9) & 0 & 0 & 6.8 \\
\hline
\end{tabular}

\begin{tabular}{|l|r|r|r|}
\hline 福井 & $\begin{array}{l}\text { 広報掲載な } \\
\text { L 非 PDF 単 }\end{array}$ & $\begin{array}{l}\text { 平均年 } \\
\text { 独 }\end{array}$ \\
\hline 市 $(\mathrm{N}=9)$ & 0 & 0 & 13.1 \\
\hline 町村 $(\mathrm{N}=8)$ & 0 & 0 & 6.3 \\
\hline
\end{tabular}

\begin{tabular}{|l|r|r|r|}
\hline 山梨 & $\begin{array}{l}\text { 広報掲載な } \\
\text { 乙 }\end{array}$ & $\begin{array}{l}\text { 非 PDF 単 } \\
\text { 独 }\end{array}$ & $\begin{array}{l}\text { 平均年 } \\
\text { 数 }\end{array}$ \\
\hline 市 $(\mathrm{N}=13)$ & 0 & 0 & 7.0 \\
\hline 町村 $(\mathrm{N}=14)$ & 0 & 0 & 10.9 \\
\hline
\end{tabular}

\begin{tabular}{|l|r|r|r|}
\hline 長野 & $\begin{array}{l}\text { 広報掲載な } \\
\text { ᄂ 非 PDF 単 }\end{array}$ & $\begin{array}{l}\text { 平均年 } \\
\text { 独 }\end{array}$ & 数 \\
\hline 市 $(\mathrm{N}=19)$ & 0 & 2 & 7.2 \\
\hline 町村 $(\mathrm{N}=58)$ & 5 & 4 & 4.9 \\
\hline
\end{tabular}

\begin{tabular}{|l|r|r|r|}
\hline 岐阜 & $\begin{array}{l}\text { 広報掲載な } \\
\text { 乙 非 PDF 単 }\end{array}$ & $\begin{array}{l}\text { 平均年 } \\
\text { 独 }\end{array}$ \\
\hline 市 $(\mathrm{N}=21)$ & 0 & 2 & 8.4 \\
\hline 町村 $(\mathrm{N}=21)$ & 1 & 3 & 4.9 \\
\hline
\end{tabular}

\begin{tabular}{|l|r|r|r|}
\hline 静岡 & $\begin{array}{l}\text { 広報掲載な } \\
\text { L }\end{array}$ & $\begin{array}{l}\text { 非 PDF 単 } \\
\text { 独 }\end{array}$ & $\begin{array}{l}\text { 平均年 } \\
\text { 数 }\end{array}$ \\
\hline 市 $(\mathrm{N}=23)$ & 0 & 3 & 7.0 \\
\hline 町村 $(\mathrm{N}=12)$ & 0 & 0 & 4.8 \\
\hline
\end{tabular}

\begin{tabular}{|l|r|r|r|}
\hline 愛知 & $\begin{array}{l}\text { 広報掲載な } \\
\text { L }\end{array}$ & $\begin{array}{l}\text { 非 PDF 単 } \\
\text { 独 }\end{array}$ & $\begin{array}{l}\text { 平均年 } \\
\text { 数 }\end{array}$ \\
\hline 市 $(\mathrm{N}=38)$ & 0 & 3 & 6.5 \\
\hline 町村 $(\mathrm{N}=16)$ & 0 & 1 & 3.9 \\
\hline
\end{tabular}

\begin{tabular}{|c|c|c|c|}
\hline 三重 & $\begin{array}{l}\text { 広報掲載な } \\
\text { し }\end{array}$ & $\begin{array}{l}\text { 非 PDF 単 } \\
\text { 独 }\end{array}$ & $\begin{array}{l}\text { 平均年 } \\
\text { 数 }\end{array}$ \\
\hline 市 $(\mathrm{N}=14)$ & 0 & 0 & 7.2 \\
\hline 町村 (N=15) & 0 & 1 & 7.7 \\
\hline
\end{tabular}

\begin{tabular}{|c|c|c|c|}
\hline 滋賀 & $\begin{array}{l}\text { 広報掲載な } \\
\text { し }\end{array}$ & $\begin{array}{l}\text { 非 PDF 単 } \\
\text { 独 }\end{array}$ & $\begin{array}{l}\text { 平均年 } \\
\text { 数 }\end{array}$ \\
\hline 市 $(\mathrm{N}=13)$ & 0 & 3 & 6.2 \\
\hline 町村 (N=6) & 0 & 1 & 5.3 \\
\hline
\end{tabular}

\begin{tabular}{|l|l|l|l|}
\hline 京都 & $\begin{array}{l}\text { 広報掲載な } \\
\text { L }\end{array}$ & $\begin{array}{l}\text { 非 PDF 単 } \\
\text { 独 }\end{array}$ & $\begin{array}{l}\text { 平均年 } \\
\text { 数 }\end{array}$ \\
\hline
\end{tabular}




\begin{tabular}{|l|r|r|r|} 
市 $(\mathrm{N}=15)$ & 0 & 0 & 11.8 \\
\hline 町村 $(\mathrm{N}=11)$ & 0 & 0 & 3.9 \\
\hline
\end{tabular}

\begin{tabular}{|l|r|r|r|}
\hline 大阪 & $\begin{array}{l}\text { 広報掲載な } \\
\text { L }\end{array}$ & $\begin{array}{l}\text { 非 PDF 単 } \\
\text { 独 }\end{array}$ & $\begin{array}{l}\text { 平均年 } \\
\text { 数 }\end{array}$ \\
\hline 市 $(\mathrm{N}=33)$ & 0 & 9 & 6.1 \\
\hline 町村 $(\mathrm{N}=10)$ & 0 & 0 & 4.9 \\
\hline
\end{tabular}

\begin{tabular}{|c|c|c|c|}
\hline 兵庫 & $\begin{array}{l}\text { 広報掲載な } \\
\text { 乙 }\end{array}$ & $\begin{array}{l}\text { 非 PDF 単 } \\
\text { 独 }\end{array}$ & $\begin{array}{l}\text { 平均年 } \\
\text { 数 }\end{array}$ \\
\hline 市 $(\mathrm{N}=29)$ & 0 & 3 & 12.6 \\
\hline 町村 (N=12) & 0 & 0 & 10.8 \\
\hline
\end{tabular}

\begin{tabular}{|c|c|c|c|}
\hline 奈良 & $\begin{array}{l}\text { 広報掲載な } \\
\text { 乙 }\end{array}$ & $\begin{array}{l}\text { 非 PDF 単 } \\
\text { 独 }\end{array}$ & $\begin{array}{l}\text { 平均年 } \\
\text { 数 }\end{array}$ \\
\hline 市 $(\mathrm{N}=12)$ & 0 & 2 & 4.6 \\
\hline 町村 (N=27) & 1 & 0 & 4.1 \\
\hline
\end{tabular}

\begin{tabular}{|c|c|c|c|}
\hline 和歌山 & $\begin{array}{l}\text { 広報掲載な } \\
\text { し }\end{array}$ & $\begin{array}{l}\text { 非 PDF 単 } \\
\text { 独 }\end{array}$ & $\begin{array}{l}\text { 平均年 } \\
\text { 数 }\end{array}$ \\
\hline 市 (N= & 0 & 1 & 6.3 \\
\hline 町村 (N=21) & 0 & 1 & 6.1 \\
\hline
\end{tabular}

\begin{tabular}{|c|c|c|c|}
\hline 鳥取 & $\begin{array}{l}\text { 広報掲載な } \\
\text { 乙 }\end{array}$ & $\begin{array}{l}\text { 非 PDF 単 } \\
\text { 独 }\end{array}$ & $\begin{array}{l}\text { 平均年 } \\
\text { 数 }\end{array}$ \\
\hline 市 $(\mathrm{N}=4)$ & 0 & 1 & 6.0 \\
\hline 町村 (N=15) & 0 & 3 & 8.3 \\
\hline
\end{tabular}

\begin{tabular}{|l|r|r|r|}
\hline 島根 & $\begin{array}{l}\text { 広報掲載な } \\
\text { L }\end{array}$ & $\begin{array}{l}\text { 非 PDF 単 } \\
\text { 独 }\end{array}$ & $\begin{array}{l}\text { 平均年 } \\
\text { 数 }\end{array}$ \\
\hline 市 $(\mathrm{N}=9)$ & 0 & 1 & 6.1 \\
\hline 町村 $(\mathrm{N}=11)$ & 0 & 1 & 6.2 \\
\hline
\end{tabular}

\begin{tabular}{|l|r|r|r|}
\hline 岡山 & $\begin{array}{l}\text { 広報掲載な } \\
\text { L }\end{array}$ & $\begin{array}{l}\text { 非 PDF 単 } \\
\text { 独 }\end{array}$ & $\begin{array}{l}\text { 平均年 } \\
\text { 数 }\end{array}$ \\
\hline 市 $(\mathrm{N}=15)$ & 0 & 4 & 5.9 \\
\hline 町村 $(\mathrm{N}=12)$ & 0 & 0 & 6.3 \\
\hline
\end{tabular}

\begin{tabular}{|l|r|r|r|}
\hline 広島 & \multicolumn{2}{|l|}{$\begin{array}{l}\text { 広報掲載な } \\
\text { L 非 PDF 単 }\end{array}$} & $\begin{array}{l}\text { 平均年 } \\
\text { 独 }\end{array}$ \\
\hline 市 $(\mathrm{N}=14)$ & 0 & 3 & 4.4 \\
\hline 町村 $(\mathrm{N}=9)$ & 0 & 0 & 8.6 \\
\hline
\end{tabular}

\begin{tabular}{|l|r|r|r|}
\hline 山口 & \multicolumn{2}{|l|}{$\begin{array}{l}\text { 広報掲載な } \\
\text { L }\end{array}$} & \multicolumn{2}{l|}{$\begin{array}{l}\text { 非 PDF 単 } \\
\text { 独 }\end{array}$} & $\begin{array}{l}\text { 平均年 } \\
\text { 数 }\end{array}$ \\
\hline 市 $(\mathrm{N}=13)$ & 0 & 3 & 5.5 \\
\hline 町村 $(\mathrm{N}=6)$ & 0 & 0 & 5.8 \\
\hline
\end{tabular}

\begin{tabular}{|l|l|l|l|}
\hline 徳島 & $\begin{array}{l}\text { 広報掲載な } \\
\text { L }\end{array}$ & $\begin{array}{l}\text { 非 PDF 単 } \\
\text { 独 }\end{array}$ & $\begin{array}{l}\text { 平均年 } \\
\text { 数 }\end{array}$ \\
\hline
\end{tabular}

\begin{tabular}{|l|l|l|l|} 
市 $(\mathrm{N}=8)$ & 0 & 1 & 6.4 \\
\hline 町村 $(\mathrm{N}=16)$ & 0 & 1 & 4.7 \\
\hline
\end{tabular}

\begin{tabular}{|l|r|r|r|}
\hline 香川 & $\begin{array}{l}\text { 広報掲載な } \\
\text { L 非 PDF 単 }\end{array}$ & $\begin{array}{l}\text { 平均年 } \\
\text { 独 }\end{array}$ \\
\hline 市 $(\mathrm{N}=8)$ & 0 & 0 & 7.5 \\
\hline 町村 $(\mathrm{N}=9)$ & 0 & 1 & 4.9 \\
\hline
\end{tabular}

\begin{tabular}{|l|r|r|r|}
\hline 愛媛 & $\begin{array}{l}\text { 広報掲載な } \\
\text { L 非 PDF 単 }\end{array}$ & $\begin{array}{l}\text { 平均年 } \\
\text { 独 }\end{array}$ \\
\hline 市 $(\mathrm{N}=11)$ & 0 & 2 & 6.9 \\
\hline 町村 $(\mathrm{N}=9)$ & 0 & 0 & 6.8 \\
\hline
\end{tabular}

\begin{tabular}{|l|r|r|r|}
\hline 高知 & $\begin{array}{l}\text { 広報掲載な } \\
\text { L }\end{array}$ & $\begin{array}{l}\text { 非 PDF 単 } \\
\text { 独 }\end{array}$ & $\begin{array}{l}\text { 平均年 } \\
\text { 数 }\end{array}$ \\
\hline 市 $(\mathrm{N}=11)$ & 0 & 1 & 10.9 \\
\hline 町村 $(\mathrm{N}=23)$ & 2 & 0 & 4.8 \\
\hline
\end{tabular}

\begin{tabular}{|l|r|r|r|}
\hline 福岡 & $\begin{array}{l}\text { 広報掲載な } \\
\text { L }\end{array}$ & $\begin{array}{l}\text { 非 PDF 単 } \\
\text { 独 }\end{array}$ & $\begin{array}{l}\text { 平均年 } \\
\text { 数 }\end{array}$ \\
\hline 市 $(\mathrm{N}=28)$ & 0 & 4 & 7.1 \\
\hline 町村 $(\mathrm{N}=32)$ & 2 & 2 & 8.1 \\
\hline
\end{tabular}

\begin{tabular}{|c|c|c|c|}
\hline 佐賀 & $\begin{array}{l}\text { 広報掲載な } \\
\text { 乙 }\end{array}$ & $\begin{array}{l}\text { 非 PDF 単 } \\
\text { 独 }\end{array}$ & $\begin{array}{l}\text { 平均年 } \\
\text { 数 }\end{array}$ \\
\hline 市 $(\mathrm{N}=10)$ & 0 & 0 & 11.9 \\
\hline 町村 (N=10) & 0 & 0 & 9.7 \\
\hline
\end{tabular}

\begin{tabular}{|l|r|r|r|}
\hline 長崎 & $\begin{array}{l}\text { 広報掲載な } \\
\text { L }\end{array}$ & $\begin{array}{l}\text { 非 PDF 単 } \\
\text { 独 }\end{array}$ & $\begin{array}{l}\text { 平均年 } \\
\text { 数 }\end{array}$ \\
\hline 市 $(\mathrm{N}=13)$ & 0 & 1 & 10.7 \\
\hline 町村 $(\mathrm{N}=8)$ & 0 & 1 & 4.6 \\
\hline
\end{tabular}

\begin{tabular}{|c|c|c|c|}
\hline 熊本 & $\begin{array}{l}\text { 広報掲載な } \\
\text { し }\end{array}$ & $\begin{array}{l}\text { 非 PDF 単 } \\
\text { 独 }\end{array}$ & $\begin{array}{l}\text { 平均年 } \\
\text { 数 }\end{array}$ \\
\hline 市 $(\mathrm{N}=14)$ & 0 & 1 & 6.4 \\
\hline 町村 (N=31) & 0 & 2 & 8.7 \\
\hline
\end{tabular}

\begin{tabular}{|l|r|r|r|}
\hline 大分 & \multicolumn{2}{|l|}{$\begin{array}{l}\text { 広報掲載な } \\
\text { L 非 PDF 単 }\end{array}$} & $\begin{array}{l}\text { 平均年 } \\
\text { 独 }\end{array}$ \\
\hline 市 $(\mathrm{N}=14)$ & 0 & 2 & 10.9 \\
\hline 町村 $(\mathrm{N}=4)$ & 1 & 1 & 5.0 \\
\hline
\end{tabular}

\begin{tabular}{|l|r|r|r|}
\hline 宮崎 & $\begin{array}{l}\text { 広報掲載な } \\
\text { L }\end{array}$ & $\begin{array}{l}\text { 非 PDF 単 } \\
\text { 独 }\end{array}$ & $\begin{array}{l}\text { 平均年 } \\
\text { 数 }\end{array}$ \\
\hline 市 $(\mathrm{N}=9)$ & 0 & 0 & 9.6 \\
\hline 町村 $(\mathrm{N}=17)$ & 1 & 1 & 4.2 \\
\hline
\end{tabular}

\begin{tabular}{|l|l|l|l|}
\hline 鹿児島 & $\begin{array}{l}\text { 広報掲載な } \\
\text { L }\end{array}$ & $\begin{array}{l}\text { 非 PDF 単 } \\
\text { 独 }\end{array}$ & $\begin{array}{l}\text { 平均年 } \\
\text { 数 }\end{array}$ \\
\hline
\end{tabular}




\begin{tabular}{|l|l|l|l|} 
市 $(\mathrm{N}=19)$ & 0 & 0 & 5.9 \\
\hline 町村 $(\mathrm{N}=24)$ & 0 & 1 & 5.6 \\
\hline
\end{tabular}

\begin{tabular}{|l|r|r|r|}
\hline 沖縄 & $\begin{array}{l}\text { 広報掲載な } \\
\text { L }\end{array}$ & $\begin{array}{l}\text { 非 PDF 単 } \\
\text { 独 }\end{array}$ & $\begin{array}{l}\text { 平均年 } \\
\text { 数 }\end{array}$ \\
\hline 市 $(\mathrm{N}=11)$ & 0 & 4 & 8.5 \\
\hline 町村 $(\mathrm{N}=30)$ & 3 & 4 & 7.2 \\
\hline
\end{tabular}

表2 自治体広報紙のWebサイト上の公開に 関する都道府県別の状況

表2については, 広報掲載がない自治体の 数とPDFのみによる公開ではない自治体の 数, そして, 公開の平均年数を示している. 表 2を見る限り，例えば都市部を多く抱える都道 府県であるから，広報紙のWebサイト上での 公開が進んでいるといったことが言えるわけで はないことが窥える. 市と町村の間で, 特徴的 な差は見出せないようである.

\section{3 自治体広報紙のアーカイブ化の}

\section{現状}

\section{1 公開の有無}

大半の自治体で，Webサイト上で何らか の形態で, 広報紙を公開していることは確 認された. 公開していない自治体について は，そのような取組みを行っていないだけ だと考えられるが，石川県珠洲市は明示的 に，広報紙のWebサイト上での公開を取り やめている例も見られる[2].

\section{2 データ形態}

現状では, 大半の自治体で PDF が活用 されている．特に過去の広報紙について は, 実物をスキャンすることで PDF 化さ れている. 画像として公開する場合には, JPEG やGIF も利用されることもあるが， これは少数である。単に過去の広報紙の
実物を公開するというだけであれば， PDF を利用することも選択肢としては 考え得るだろう。

一方で，広報紙のデータを元に，独自 のページをサイト上に構築している例も ある。この例では，データの形態は HTML である。この場合，広報紙の記事 に関する文字列の検索などが容易であり， さらに，再利用も可能である，実物をス キャンして保存されたものである場合， 必ずしも文字検索は容易でない。

昨今では, PC 以外にスマートフォンを 介して Web サイトにアクセス寸る例も 増えている，その傾向に合わせて，スマ ートフォンからのアクセスに対応したビ ユーワーを提供している自治体もある。 また，PDFを読み取るソフトをインスト 一ルせずとも，広報紙を閲覧出来るよう に，専用のビューワーを用意している自 治体もある。

\section{3 年数}

アーカイブ化と言う以上，可能な限り 過去に遡って，データを整理する必要が あると考えられるが，一部に長期公開年 数を誇る自治体がある一方で, 10 年に満 たない年数の自治体も数多い. 長期公開 年数を誇る自治体として，20 年以上の蓄 積があるのは 48 自治体である.さらに， その中でも, 60 年以上の蓄積を誇る自治 体が 16 ある. 対して, 一桁年数の蓄積し かない自治体が 1503 あり，うち 1 年分 が 155 自治体, 0 年が 51 自治体ある [3].

公開されている年数について特徵的な 例としてあげられるのが，秋田県の秋田 市や能代市である。秋田市では，創刊以 来の 62 年分の広報紙が専用のサイトで 
閲覧可能である. 能代市についても同様 の取り組みを行っている.

両市は，各記事について，文字がデー 夕化され，用語検索なども可能である. 創刊以来の広報紙が Web サイト上で公 開されている自治体は他にも存在するが， それらの例では, 広報紙が PDF 化した上 で公開されるに留まり，用語検索などは 行えない。この点をもって，秋田市や能 代市は他にはない特徵を備えており，今 後の広報紙のアーカイブ化の先例となり 得る存在であると言える。

神奈川県小田原市は，市政記念事業と して過去の 63 年分の広報の公開を進め ている．自治体の広報紙には，当該地域 の歴史が蓄積されている。市政記念事業 として，その歴史を振り返り，後世にも 伝えていくという意味で，広報紙の保存 と公開を図ることは有効な施策となるだ ろう。ただし，この場合，広報紙自体の 保存・公開に重点が置かれ，アーカイブ として後に別の形で利活用することまで は想定されたものにはなっていない.

埼玉県富士見市は過去の広報紙のデー タについて, 図書館の Web サイト上で公 開している。自治体の発行した各種の資 料を図書館は収蔵することは一般的であ ると考えられる。そこで，行政と連動し て図書館が広報紙のアーカイブ化を進め るという方式も一つの選択肢として検討 され得ると考えられる。

長崎県大村市は，政府の緊急雇用対策で 得た資金を活用して，過去61年分の広報紙 をPDF化して, 公開している[4]. 過去に発 行した広報紙の保存や公開という事業は 必ずしも政策的な優先順位が高くないも のと考えられるが，そのような事業におい
て，臨時の資金を活用するという方法は参 照され得るものである.アーカイブ化され た広報紙は，後の利用が想定されるため， 単発の資金の活用としての有効性も高い。

大仙市は，合併前の 8 市町村の昭和 20 年 代の広報紙を網羅した特別なサイトを開 設している。このように，地域の歴史を語 り継ぐために，広報紙を保存・公開する例 も存在している.

大分県大分市は64年分, 宮崎県日向市が 57年分の広報紙について，専用のサイトを 構築して公開している。単にPDF化した広 報紙を列挙しているだけの自治体も多い が，このように，利用者の利便性を考えた 公開の方法を考えることが今後は重要に なると考えられる.

\section{4 自治体広報紙のア一カイブ化の}

\section{課題}

現状では，過去に発行した広報紙を Web サイト上で公開することが主眼とさ れていることが課題としてあげられる. ただし，本研究では，市町村の Web サイ トにおける広報紙の公開状況を調查して いるため, Web サイト上での公開に重点 が置かれているということが課題として 強調され過ぎてしまう可能性もある。

ICT の利用を前提とせずとも，アーカ イブ化は可能であり，過去の広報紙を縮 小化して集約し，冊子として提供してい る例もある。このように，過去の情報を 集約化し，後に利用可能な形にすること も，アーカイブ化であるが，情報社会に あっては，ICT を活用した情報の整理や 保存，Web を活用した公開を前提にせざ 
るを得ず，アーカイブ化にあたっても， それらの要因を考慮する必要がある。現 状では, 自治体の広報紙については, Web サイト上の公開という点に重点が置かれ ており，後の活用が想定されていないこ とが課題である。今後は, 整理と保存か ら公開，そして，再利用まで一貫して捉 えた上で，当該自治体に関する各種の情 報が掲載されている広報紙の取り扱いを 考えていく必要がある.

表 2 からは，昨年の東日本大震災で津 波の被害に遭った自治体が多い宮城・岩 手・福島の各県の平均年数について他の 地域と大きな差がないことが確認出来る. しかし，特に津波などにより庁舎やサー バに被害があった自治体を見ると，平均 年数が短い。自治体が発行する広報紙に は，当該地域に歴史や記憶が刻まれてお り，それらを失うことの影響は，単なる 物理的な損害を越えて大きなものである. 市政周年記念の事業として，広報紙のア 一カイブ化を進める自治体があることは 先に指摘したところであるが，自治体が 発行し続けてきた広報紙には単なる地域 の情報以上の価值が秘められている。災 害の有無に関わらず，通常時から，広報 紙など自治体が所有する情報の整備と保 存が課題の一つとして認識される必要が あるものと考えられる。

また, アーカイブとして, 後の利用が 可能となるように，データベース化した り，専用のサイトを構築したりすること も今後は課題として認識される必要があ るものと考えられる。

\section{5 まとめと考察}

本研究では, 自治体が発行する広報紙の アーカイブ化について, Webサイト上の公 開状況を調査することで，その進展状況を 確認した. 公開の方式や公開年数には差が あるものの, 多くの自治体で過去に発行し た広報紙をWebサイト上でしていること が確認出来た。なかには，秋田市のように 過去の広報紙のデータを整理し，データベ 一ス化している例も見られた。このように， 自治体の広報紙のアーカイブ化は進みつ つあると結論付けられるだろう。

今後の研究上の課題としては, Webサイ 卜上では公開していないものの，自治体内 部では広報紙のアーカイブ化を進めてい る例も存在すると考えられることから，そ のような例について探索することがあげ られる。また，広報紙に限らず，自治体が 保有する各種情報について，そのアーカイ ブ化が如何に進められているのか。あるい は, 進んでいないのか. その事例研究を追 加的に行うことも研究上に残された課題 としてあげられる。

\section{参考文献}

［1］笠羽晴夫：『デジタルアーカイブの構 築と運用ミュージアムから地域振興へ』。 水曜社，p. 191-，2004，

[2]市の電子会議室である http://www. city. suzu. ishikawa. jp/home /scripts/denshikaigi/kaigi/dobbsrr. cg $i$ ?a=vi ew\&topic_id=1262655972\&res_id=1 50に，その経緯が示されている. [3]一桁年数の自治体及び0年の自治体に は，Webサイトでの広報紙の公開を行って いない自治体も含まれる。

［4］村崎浩史大村市議会議員より伺った。 